IZA DP No. 6719

The Effects of Credit Status on College Attainment and College Completion

Dora Gicheva

Felicia lonescu

Nicole Simpson

July 2012 


\title{
The Effects of Credit Status on College Attainment and College Completion
}

\author{
Dora Gicheva \\ UNC-Greensboro
}

Felicia Ionescu

Colgate University

Nicole Simpson

Colgate University

and IZA

\section{Discussion Paper No. 6719 \\ July 2012}

\section{IZA}

\author{
P.O. Box 7240 \\ 53072 Bonn \\ Germany
}

\author{
Phone: +49-228-3894-0 \\ Fax: +49-228-3894-180 \\ E-mail: iza@iza.org
}

\begin{abstract}
Any opinions expressed here are those of the author(s) and not those of IZA. Research published in this series may include views on policy, but the institute itself takes no institutional policy positions.

The Institute for the Study of Labor (IZA) in Bonn is a local and virtual international research center and a place of communication between science, politics and business. IZA is an independent nonprofit organization supported by Deutsche Post Foundation. The center is associated with the University of Bonn and offers a stimulating research environment through its international network, workshops and conferences, data service, project support, research visits and doctoral program. IZA engages in (i) original and internationally competitive research in all fields of labor economics, (ii) development of policy concepts, and (iii) dissemination of research results and concepts to the interested public.
\end{abstract}

IZA Discussion Papers often represent preliminary work and are circulated to encourage discussion. Citation of such a paper should account for its provisional character. A revised version may be available directly from the author. 


\section{ABSTRACT
The Effects of Credit Status on College Attainment and College Completion

College students now use various forms of unsecured credit such as private student loans and credit cards to finance college. Access to these credit lines and the interest rates charged on these loans can vary significantly across credit scores. In this paper, we analyze if credit status, as measured by self-reported characteristics of an individual's credit standing, affects college investment. Using data from the Survey of Consumer Finances, we study a sample of young high school graduates to estimate how three different measures of credit status affect college attainment and completion rates. After correcting for selection and endogeneity issues, we find that credit status is more important the longer the student stays in college. For example, having bad credit significantly lowers the probability of completing a four-year college degree, but has a smaller (but significant) impact on attaining some college. We find robust evidence that credit status affects the intensive margin of college investment, but is less important for the extensive margin. Our results suggest that bad credit status, which lowers the availability of unsecured credit to finance college and thereby makes college investment more expensive, significantly reduces college completion rates.

JEL Classification: $\quad$ I20, G10

Keywords: college investment, credit scores, financial markets

Corresponding author:

Nicole Simpson

Colgate University

Department of Economics

13 Oak Drive

Hamilton, NY 13346

USA

E-mail: nsimpson@colgate.edu

\footnotetext{
* The authors would like to thank Meta Brown, Matt Johnson, Sarah Turner, and brown bag participants at UNC-Greensboro and Colgate University for comments and suggestions. All errors are our own.
} 


\section{Introduction}

In this paper, we study the effect of credit status, as measured by self-reported repayment behavior and credit standing, on college investment. The increased use of private sources of credit to finance college in the last two decades, such as private student loans and credit cards, whose eligibility is often based on credit scores, allows for the possibility that credit status (i.e., having good or bad credit) affects the ability to pay for college. If so, then credit status can impact the decisions to attain some college (i.e., having at least one year of college education) and complete college (i.e., a four-year undergraduate degree). This topic is especially relevant given that college enrollment rates in the U.S. are currently at record highs, but college completion rates are abysmal $\left.\right|^{1}$

Student loan borrowing has garnered a lot of national attention recently since two-thirds of bachelor's degree recipients (in 2007-2008) borrow money from the government or private lenders to finance college, and the average amount borrowed (in 2011) is $\$ 23,300$ (Steele and Baum (2009): Brown et al. (2012)). While government student loan programs have existed since 1965, borrowing from private lenders for college is a relatively new phenomenon. Beginning in the early 1990's, students have been able to borrow directly from banks, credit unions and schools to finance their college education. The volume of nonfederal, private student loans reached the level of $\$ 24$ billion in 2007-08 (in 2010 dollars), which represented 26 percent of total student loan volume (College Board (2011)); this compares to 4 percent of student loan volume in 1995-1996 and virtually zero in the early 1990s (College Board (2006)). ${ }^{2}$ Among undergraduates who borrow for college, approximately 30 percent borrow from the private market, borrowing on average $\$ 7,809$ (Steele and Baum (2009); Gallup and Sallie Mae (2008) ? $^{3}$ Thus, the private student loan market is an important source of borrowing for many college students.

Borrowing from the private market for college is very different than borrowing from the government. The most important difference is that credit measures, such as credit scores, are not required for government student loans, but are a key element in determining loan eligibility in the private market. Credit scores dictate both the interest rate private creditors charge and the amount lent to each individual. Thus, credit scores directly impact the availability and price of funds for students to finance college.

\footnotetext{
${ }^{1}$ The Wall Street Journal article "Education Slowdown Threatens U.S." by D. Wessel and S. Banchero on April 26, 2012 states that 70\% of high-school graduates enroll in a two- or four-year college soon after finishing high school and $43 \%$ of those who enrolled as freshmen at four-year colleges in 2002 hadn't received a degree six years later.

${ }^{2}$ Since the credit crisis of 2007-08, the volume of private student loans has significantly decreased, but most experts expect it to recover to pre-crisis levels in the near future.

${ }^{3}$ The estimates for graduate students are higher, and especially among students in professional graduate programs, such as MBA, law and medical school, where nearly a quarter of students borrow from the private market (Institute for Higher Education Policy (2006)).
} 
Another important source of unsecured credit for college is credit cards. Credit card usage is rampant among college students, with approximately 84 percent of the student population having at least one credit card (in 2008), and 39 percent arriving on campus with a credit card in-hand (Sallie Mae (2009)). In addition, credit cards are often used as direct sources of college financing. In fact, Sallie Mae (2009) reports that 30 percent of undergraduate credit cardholders put tuition on their credit card and 92 percent charge textbooks, school supplies, or other direct education expenses ${ }^{4}$ As students proceed through college, they use their credit cards more heavily, with seniors having with more credit card debt than first-year students (Sallie Mae (2009)).

Credit scores impact the availability of unsecured credit and are established once somebody starts using credit. Young adults with little to no credit usage have very little credit history. However, Sallie Mae (2009) reports that only two percent of undergraduates have no credit history. Importantly, credit scores evolve over time as credit usage increases and the length of the credit history expands, so that credit scores increase with age. A 2005 report by Experian National Score Index finds that the average credit score for the youngest demographic, ages 18 to 29 , is $637 !^{5}$ People ages 30 to 39 have higher average scores of $6545^{6}$ This evidence indicates that young adults are very likely to have a credit history and access to credit markets.

Given that more college students are using private sources of credit to finance their college education (through the private student loan market and/or credit cards) and since credit scores are an important determinant of access to these markets, it is reasonable to think that credit scores (or more broadly, credit status) affect the ability to finance college and hence the college investment decision. In fact, credit status could affect both the decision to enroll in college (i.e., the extensive margin) and the amount of college education to invest in (i.e., the intensive margin). In this paper, we attempt to determine if there is a relationship between credit status and college education, and if so, to quantify the effects of credit status on both attaining some college and completing a four-year college degree. Understanding the relationship between credit status and college investment may shed some light on the existence of credit constraints for financing college. Since access to unsecured credit markets is determined by credit status, by estimating the impact of credit status on college attainment and completion, our results could be intrepreted to indicate that college students are credit constrained in the absence of these markets.

It is likely that the group of students for which credit scores matter most for college investment is independent students.7 In recent years, they represent more than one half of all college

\footnotetext{
${ }^{4}$ Students who used credit cards to pay for direct education expenses estimated charging $\$ 2,200$ on average to their credit cards.

${ }^{5}$ FICO credit scores range from 300 to 850 points.

${ }^{6}$ http://www.nationalscoreindex.com/ScoreNews_Archive_07.aspx

${ }^{7}$ Students are considered independent if they are over 24 years old, married, parents, or veterans of the
} 
students in the U.S. (Wei et al. (2005)). Independent students are different from dependent students in important ways: they are older, more likely to attend college part-time, have higher living costs (because of their families), attend for-profit institutions and community colleges at higher rates, and are more likely to be employed (Wei et al. (2005)). They also finance their college education differently: they have access to larger government student loans but their household income often reduces eligibility, and they also are more likely to use a variety of other resources in addition to financial aid to pay for their education (Wei et al. (2005)). In fact, independent students are more likely to carry a credit card balance than dependent students, and among those who carried a balance, the average credit card debt was higher (Wei et al. (2005)). 8 Given their age and financial situation, it is likely that credit scores are an important factor in the college attainment of independent students. In our dataset, we are not able to identify independent students per se, but we restrict our analysis to people ages 23-40, whereby independent students likely constitute a significant part of the sample.

We use data from the Survey of Consumer Finances (SCF) that contain information about the credit status of individuals and their level of college education. Unfortunately, credit scores are not reported in publicly-available micro datasets, including the SCF. However, the SCF contains detailed information about the various types of credit that households use and information related to the credit status of the person interviewed. For example, the SCF asks respondents about their repayment behavior, the main component in the credit score calculation 99 The SCF also asks respondents if they have been turned down for any type of credit and if being turned down was due to having bad credit.

It is plausible that the relationship between college education and credit status works two ways: that credit status affects college education via the credit channel, and that college education, by affecting lifetime income, affects future credit status. For this study, we focus on the former but attempt to address the endogeneity issue in two ways. First, we measure the effect of credit status on college education for young high-school graduates (age 23-30) and compare the results to older high-school graduates (age 31-40). The young cohort helps us to isolate the effect of credit status on income since it is less likely that that their incomes have evolved enough to affect their credit status early in life. The second group is young enough such that the feedback of income on credit status should still be quite low, but it is likely that both mechanisms are at play (that credit status affect educational attainment and vice versa). In addition, we control for endogeneity by employing a Heckman two-step model with college education as the dependent variable in the second stage and various measures of credit status as military.

${ }^{8}$ The NCES data cannot determine if credit cards were used specifically to pay for educational expenses. The Education Resources Institute, Inc. (1998) cites that $27 \%$ of independent students use their credit cards to charge tuition and fees, which is almost double the rate cited for dependent students.

${ }^{9}$ http://www.myfico.com/CreditEducation/WhatsInYourScore.aspx 
independent variables. The selection we control for is whether individuals have credit history, as measured by our credit status variables.

Our main finding is that credit status positively affects college education, and in particular, the intensive margin of college education. Specifically, three different measures of bad credit status (having bad credit, being turned down for credit, and hardly ever repaying credit card balances) are all negatively correlated with more years of college education and the probability of completing a four-year college degree. We find evidence of a weaker relationship between credit status and the decision to attain some college. Thus, credit status becomes more important the longer students remain in college. These results are robust to various functional form specifications, variable definitions and sample restrictions.

\subsection{Related Literature}

To our knowledge, we are the first to estimate an empirical relationship between credit status and college investment. In recent work, Ionescu and Simpson (2011) study the role of credit status on the college investment decision in a quantitative macroeconomic framework. A unique feature of the model in Ionescu and Simpson (2011) is that credit status impacts which students use the private student loan market to finance college expenditures. The focus of that paper is to show how the government student loan program and the private market for student loans interact with one another when households are credit-constrained. In fact, Ionescu and Simpson (2011) document that both markets are important for low-income students. This work is related to Lochner and Monge-Naranjo (2011) who also incorporate the private market for student loans, but do not explicitly consider the role of credit status.

There is literature, initiated by Becker and Tomes (1979), that emphasizes the relevance of credit constraints and family income on schooling decisions. Recent empirical research documents that long-run family factors (such as parental income) are far more decisive in promoting college readiness than short-run credit constraints 10 The results of Carneiro and Heckman (2002), Cameron and Taber (2004) and Stinebrickner and Stinebrickner (2008), in particular, indicate that financial constraints during college-going years are not crucial for college enrollment. Brown et al. (2009), however, suggest that borrowing constraints are important for students whose parents are unwilling or unable to meet their expected family contribution for college. Still, it is difficult to pinpoint whether or not credit constraints exist for college investment, and if so, to what extent (Turner (2004)).

It is well-documented that government subsidies and the government student loan program both play important roles in college enrollment and completion 11 Evidence by Lochner and ${ }^{10}$ See Cameron and Heckman (1998), Cameron and Heckman (2001), Cameron and Taber (2004), Carneiro and Heckman (2002), and Keane and Wolpin (2001).

${ }^{11}$ Refer to Dynarski (2002), Kane(2003), Dynarski (2003), Turner(2004), Dynarski (2005), Akyol and Athreya 
Monge-Naranjo (2011), IHEP (2006) and Gallup and Sallie Mae (2008) suggest that the government student loan program in the U.S. is not meeting the needs of some students, pushing them to use private credit markets to finance at least part of their college education. Since these markets rely on credit status (i.e., credit scores) to determine loan eligibility and conditions, quantifying the extent to which credit status affects college investment will be of interest to policymakers, especially as credit markets continue to evolve over time.

The paper is organized as follows. In this next section, we specify the Heckman two-step model, which is followed by a description of the SCF sample used in the analysis. We present our empirical findings on how various credit measures affect college attainment and completion, and discuss how our results add to the existing literature on the determinants of educational attainment at the college level. We report several robustness checks, and conclude by discussing some directions for further research.

\section{Model}

In this paper, we attempt to isolate the effect that credit status has on educational attainment. The main empirical specification is a regression with educational attainment as the dependent variable and credit status as the relevant independent variable. This specification is potentially plagued by two problems: selection bias and endogeneity. In what follows, we discuss how we attempt to mitigate these issues.

We are interested in three different measures of credit status (described in detail in Section 3) as explanatory variables. The credit status variables are not available for the entire sample, with nonrandom missing observations. Specifically, they are observed only when the respondent has recently applied for a loan or holds a credit card. However, it is plausible that whether one applies for a loan or holds a credit card is correlated with educational attainment, in which case sample selection issues may result in biased estimates.

To correct for potential selection problems, we use a Heckman two-step estimation model, in which the first stage is a probit with the dependent variable indicating whether one applied for credit or holds a credit card. The first stage of the selection model is estimated on all high school graduates in the relevant age group, regardless of whether they applied for credit or use a credit card. The controls in the first stage predict who is more likely to apply for credit or use a credit card. For example, those who think it is fine to use credit to buy luxury goods are more likely to have a credit card.

The regressions for the first stage are:

(2005), Garriga and Keightley (2007), Ionescu (2009) and Johnson (2010). 


$$
\begin{gathered}
\operatorname{Prob}(\text { Loan }=1)=\operatorname{Prob}\left(\alpha+\beta \cdot X+\gamma \cdot Y+\varepsilon_{1}>0\right) \\
\operatorname{Prob}(\text { Credit } \text { Card }=1)=\operatorname{Prob}\left(\alpha+\beta \cdot X+\gamma \cdot Y+\varepsilon_{1}>0\right)
\end{gathered}
$$

where Loan (Credit Card) is an indicator variable that takes the value 1 if the respondent applied for a loan (holds a credit card), $X$ is a vector of demographic variables (female, race, married, household size, age and age-squared), and $Y$ is a vector of dummy variables indicating attitude towards credit. The vectors $(\alpha, \beta, \gamma)$ are the estimated coefficients and $\varepsilon_{1}$ is the normally distributed random error term. The vector $Y$ representing attitudes towards credit is excluded from the second stage. The underlying assumption is that such attitudes towards credit are not directly related to college investment.

The second stage is estimated only on the sample of people who use credit (i.e., whether they have applied for a loan or use a credit card). If we only ran this regression, we would estimate the relationship between credit status and college attainment only for those who use credit. The problem is that it is not necessarily the case that the relationship is the same for users of credit and all high school graduates; in fact, it is likely that credit status matters more for those who use credit. The two-step estimation procedure produces parameter estimates that are applicable for the entire population of high school graduates, those who have applied for a loan or have a credit card and those who have not.

The second stage of the selection model is either a linear regression, where the dependent variable is years of education (in equation 3 below), or a linear probability model with binary dependent variables for all other outcomes (equations 4 and 5). The second stage specifications are thus:

$$
\begin{aligned}
& \text { Years of Education }=\lambda+\nu \cdot \text { credit measure }+\mu \cdot Z+v \cdot X+\varepsilon_{2} \\
& \text { College attainment }=\lambda+\nu \cdot \text { credit measure }+\mu \cdot Z+v \cdot X+\varepsilon_{2} \\
& \text { College degree }=\lambda+\nu \cdot \text { credit measure }+\mu \cdot Z+v \cdot X+\varepsilon_{2}
\end{aligned}
$$

where credit measure is either the variable bad credit, turned down or hardly ever repay, as 
defined in Section 3 . The vector $Z$ includes aggregate college enrollment rates, an indicator if household wages are positive, and an interaction term between the natural logarithm of household wages and those with positive wages. The vector $X$ is a vector of demographic variables defined above, $(\lambda, \nu, \mu, v)$ are the vectors of estimated coefficients, and $\varepsilon_{2}$ is the random error term.

Respondents with a higher willingness to use credit (positive values of the $Y$ variables) or those with more knowledge about using credit (measured by higher $\varepsilon_{1}$ ) will be more likely to have a credit card and thus more likely to have a credit status (such as a credit score). Thus, the sample may consist of respondents who have higher rates of financial literacy. This on its own does not bias the estimation in our analysis as long as $\varepsilon_{1}$ and $\varepsilon_{2}$ are uncorrelated.

The second selection effect, which is the most important, is that some respondents who do not think credit is a good idea or do not understand its value still use credit. These respondents have $Y$ variables equal to 0 but decide that credit is worthwhile because they have a high value for credit usage that is unobserved. In other words, these respondents get into our sample not because they think credit is a good idea, but because they have large error terms $\varepsilon_{1}$. In contrast, respondents in our sample who value credit will have less variation in errors. If the unobserved reasons for credit usage consistently lead to higher (lower) investment in college, meaning that the correlation between $\varepsilon_{1}$ and $\varepsilon_{2}$ is nonzero, then we will underestimate (overestimate) the effect of credit status on college investment without the two-stage selection model. As a concrete example, it is plausible that health shocks to respondents would generate high values of $\varepsilon_{1}$ if additional resources are needed to cover medical expenses; however, if health problems negatively affect college investment, values of $\varepsilon_{2}$ will be low. Alternatively, the correlation between the two error terms would be positive if better job offers for high school graduates are associated with low values of both $\varepsilon_{1}$ (because higher wages make credit less necessary) and $\varepsilon_{2}$ (because the opportunity cost of acquiring more education is higher). A problem we do not account for is the potential correlation between attitudes towards (or knowledge of) credit, as measured by $Y$, and the unobserved reasons for credit usage in the overall population $\left(\varepsilon_{1}\right)$. Such correlation would bias the first-stage results, but we have no explicit way of dealing with this bias. Still, we believe that this model is able to accurately pinpoint the effect of credit status on college investment, with these caveats in mind.

It is plausible that education increases earnings, and people with higher earnings have better credit status, thus we would see a positive relationship between credit status and educational attainment even if bad credit has no effect on education. Ideally, to control for endogeneity, we would like to use an Instrumental Variable (IV) approach. However, finding an appropriate instrument that is correlated with credit status but not educational attainment has proven to be difficult (if not impossible). For example, the SCF data do not contain geographic variables so we cannot use state-specific policies or shocks, which are often good candidates for IV's. 
To mitigate the endogeneity concerns beyond using the Heckman selection model, we focus on young adults where the effects of educational attainment on credit status via earnings should be minimal and compare our results for older adults where endogeneity may be more prevalent. If endogeneity is an issue, we believe it would be more relevant for the older age group, where the likelihood of educational attainment affecting credit status is higher since they have had more time to participate in credit markets after college. However, most of this group is too old to have participated in credit markets during college in a way that credit scores would have mattered. The very youngest cohort in the older sample would have been in college between 1994 and 1998. The private market for student loans did not exist until the mid-1990s and credit card usage to finance college-related expenses was minimal.

We also consider various specifications with and without earnings to get a sense of the magnitude and direction of potential biases. Our results are very robust, making us confident that we are accurately capturing, albeit imperfectly, a positive effect of credit status on college investment. A more thorough discussion can be found in Section 5 .

\section{Data}

We use the Survey of Consumer Finances which is sponsored by the Federal Reserve Board in cooperation with the Department of the Treasury. The SCF collects cross-sectional samples of the U.S. population, and each installment surveys a different group of approximately 4,500 families. The survey, conducted triennially, collects detailed information about respondents' financial assets, borrowing experiences, and general attitudes toward credit. Based on a recent paper by Brown et al. (2011), the SCF data are comparable to the new FRBNY Consumer Credit Panel in terms of reported debt levels and bankruptcy rates (with the exception of credit card debt, which is understated in the SCF).

The SCF is unique in that it provides information about both credit status and educational attainment. Other datasets contain more detailed information about the college experience but provide very little data on credit status. Examples include the Beginning Postsecondary Students (BPS:04/09) and High School and Beyond: Educational Attainment of 1980 High School Sophomores by 1992 (HS\&B:92) ${ }^{12}$ Thus, the SCF seems to be the most appropriate dataset for the purposes of this study.

We use the five SCF surveys conducted between 1995 and 2007. The SCF is not a longitudinal survey but instead represents a cross-section of the population at various points in time. We analyze the 1995-2007 period since there have been significant changes in the use of private

\footnotetext{
${ }^{12}$ For example, the BPS:04/09 has some credit-related measures but consists only of students who are already enrolled in college. This contrasts to the HS\&B:92 dataset that includes high-school students (including those who do not attend college), but reports only basic measures of credit, including the size of monthly payments on cars and mortgages.
} 
credit to finance college. For example, at the start of this period, the private market for student loans was non-existent and credit cards were less available to college students ${ }^{13}$

Our unit of observation is survey respondents, rather than the household heads, because we use the information in the credit attitude questions, which pertains to survey respondents. The person interviewed is the household head 73 percent of the time in our data. We keep only the first of the five imputations provided in the public use data, but the results are not sensitive to our choice of imputation 14

Since we study decisions about higher education, we focus on high school graduates with and without college education. Those with a college education include those who have already completed their college education and those who are planning to invest more in the future (which we cannot differentiate in the SCF). Our sample consists of both dependent and independent college students, with the exception of currently-enrolled dependent students who are excluded (since the SCF does not report much information about dependent adult children). Therefore, all of the respondents in our sample are financially independent of their parents at the time of survey.

We separate the estimation based on age by grouping individuals between the ages of 23 and 30 and the ages of 31 and 40. The cut-off of age 23 is purposefully set to exclude the majority of dependent college students; for dependent students, the credit status of parents could significantly affect college investment 15 The sample sizes for each survey year of the SCF are reported by age group in Table 1. The older sample is larger than the younger sample in all survey years, but the distribution of age groups across survey years is similar. In addition, the latest survey (2007) is slightly smaller than earlier surveys. Importantly, the age distribution in the SCF is nationally representative for those age 65 and below, based on Census data and the FRBNY Consumer Credit Panel (Brown et al. (2011)).

The SCF does not provide credit scores, so we use other available measures of credit status in the SCF that are likely to be highly correlated with the scores issued by credit bureaus. Credit reporting agencies such as FICO calculate credit scores for individuals based on a large set of information about their past credit history. FICO reports that the following components form part of the credit score calculation: payment history (35\%), amount of outstanding debt (30\%), length of credit history (15\%), new credit/recent credit inquiries (10\%), and types of credit used $(10 \%){ }^{16}$ Our measures of credit status (described below) directly account for payment history and type of credit used. It is important to note that credit scores are based on information found

\footnotetext{
${ }^{13}$ Sallie Mae (2009) reports that fewer undergraduates had credit cards in 1998 compared to 2008, and credit card balances were smaller.

${ }^{14}$ For a full description of the SCF imputations, refer to Kennickell $(1998)$.

${ }^{15}$ While the credit status of parents may be relevant for college investment, we are not able to isolate this relationship using SCF data since we do not observe the educational attainment of the child.

${ }^{16} \mathrm{http}: / /$ www.myfico.com/CreditEducation/WhatsInYourScore.aspx
} 
Table 1: Sample Sizes by Survey Year

\begin{tabular}{|c|c|c|c|}
\hline Year & $23 \leq$ Age $\leq 30$ & $31 \leq$ Age $\leq 40$ & Total \\
\hline \hline 1995 & 475 & 755 & 1,230 \\
\hline & $(38.62 \%)$ & $(61.38 \%)$ & \\
\hline 1998 & 406 & 722 & 1,128 \\
\hline & $(35.99 \%)$ & $(64.01 \%)$ & \\
\hline 2001 & 389 & 712 & 1,101 \\
\hline & $(35.33 \%)$ & $(64.67 \%)$ & \\
\hline 2004 & 380 & 662 & 1,042 \\
\hline & $(36.47 \%)$ & $(63.53 \%)$ & \\
\hline 2007 & 366 & 613 & 979 \\
\hline & $(37.39 \%)$ & $(62.61 \%)$ & \\
\hline
\end{tabular}

in credit reports, and do not explicitly depend on age, income, employment tenure, education, assets, etc. However, length of credit history is strongly positively correlated with age, ${ }^{17}$ and by controlling for age, we are able to account for this important component of credit status.

We develop three different measures of credit status from the SCF, reported in Table 2. Our first measure of credit ('turned down') is based on whether somebody in the respondent's household had been denied an application for credit during the past five years or failed to obtain the full amount requested $\sqrt{18}$ The variable 'turned down' is set to equal one if either of these events were reported. Our second measure of credit status ('bad credit') is based on the particular reason for having been turned down for credit. In particular, we use the following options: "Haven't established a credit history," "Credit rating service/credit bureau reports," "Credit records/history from other institution; other loans or charge account; previous payment records; bankruptcy," and "Bad credit." If any of these options were chosen, we assign a value of one to the bad credit variable 19 The third variable is based on respondents who reported that a member of their household has at least one credit or charge card, excluding debits cards and cards used entirely for business. Credit card holders are asked if they "almost always, sometimes, or hardly ever pay off the total balance owed on the account each month." The variable 'hardly ever repay' equals one for respondents who chose the "hardly ever" option. Table 2 summarizes the credit measures described above.

\footnotetext{
${ }^{17}$ http://www.bcsalliance.com/credit_averagescores.html

${ }^{18}$ Note that in the case of married households, we are implicitly assuming that the credit statuses of the respondent and their spouse are highly correlated, which may not always be the case. In our robustness checks, we analyze only single households (where this is not an issue) and find that our main results remain unchanged.

${ }^{19}$ There are more than 50 different responses that are reported as reasons for being turned down (using the SCF variable X7585). However, approximately two-thirds of the responses fell into the four categories listed here. The other reasons for being turned down that borrowers reported were related to debt and income levels (in approximately $25 \%$ of the responses).
} 
Table 2: Description of Credit Measures

\begin{tabular}{|l|l|}
\hline Variable & Description \\
\hline \hline Bad credit & $=1$ if turned down for any type of credit in the last five years \\
\hline & due to having bad credit \\
\hline Turned down for credit & $=1$ was a denied application for credit during the past five years \\
\hline & or failed to obtain the full amount requested \\
\hline Hardly ever repay & $=1$ if hardly ever pay off the total balance owed on the \\
\hline & credit card account each month \\
\hline
\end{tabular}

The credit measures are not universally available, requiring us to restrict our sample. The first two variables ('bad credit' and 'turned down') are available only for individuals who applied for credit in the five years prior to their interview, while the third variable ('hardly ever repay') is available for respondents with at least one credit card. Tables 3 and 4 report that approximately 81 and 82 percent of the young and old samples, respectively, applied for credit in the last five years, while 71 percent of the young sample and 79 percent of the older sample has a credit card. The younger sample has worse credit overall: more have been turned down for credit (37 percent compared to 28 percent in the older sample), more have bad credit (23 percent vs 16 percent), and slightly more hardly ever repay their credit card balance (24 percent vs 23 percent).

The variables used in the first stage of the selection model (the vector $Y$ ) and excluded from the main equation of interest are based on several SCF questions about respondents' attitudes towards credit. They include: shops around for credit, thinks installment plan is a good idea, thinks it is okay to use credit to pay for vacations, fur coats or jewelry, cars, and for living expenses if income falls. The first variable is derived from the SCF question, "When making major decisions about borrowing money or obtaining credit, some people shop around for the very best terms while others don't. What number would (you/your family) be on the scale?" Based on a five-point scale with 5 being "A great deal of shopping," our variable is set to equal 1 when respondents answered a 4 or 5 . The next question we use is: "In general, do you think it is a good idea or a bad idea for people to buy things on the installment plan?" The answers "Good idea" and "Good in some ways, bad in others" are coded as one and "Bad idea" is coded as zero. Finally, we use four parts of the following inquiry: "People have many different reasons for borrowing money which they pay back over a period of time. For each of the reasons I read, please tell me whether you feel it is all right for someone like yourself to borrow money..." The scenarios we concentrate on are "to cover the expenses of a vacation trip," "to cover living expenses when income is cut," "to finance the purchase of a fur coat or jewelry," and "to finance the purchase of a car.'20 The provided answers are binary (yes/no), and so are the resulting

\footnotetext{
${ }^{20}$ We do not use "to finance educational expenses" because this variable would likely have a more complex relationship with the schooling outcomes we study.
} 
variables. The summary statistics for these variables are reported in Tables 3 and 4 .

In terms of educational attainment, the SCF reports the highest grade of school or year of college completed by the respondent. The SCF also asks if the respondent got a college degree, and if so, the highest degree earned. However, the SCF does not report specific information about the college experience, including the type of college attended, when the degree was earned, whether the student was full- or part-time, and the dependency status of the student during college. By restricting our analysis to those age 23 and older, our sample primarily consists of currently-enrolled independent students and individuals who have completed their college education.

We consider three measures of educational attainment, which allows us to analyze both the intensive and extensive margins of college investment (recall that all respondents in the sample have a high school degree or equivalent). First, we use years of education for the full sample based on the highest grade completed. We then define 'college attainment' which equals zero for high school graduates with no post-secondary education and one for respondents who completed at least one year of college education (i.e., those who reported more than 12 years of education). Using this variable, we can analyze the factors that affect the decision to attain some college (i.e., the extensive margin). Then, we develop an indicator for respondents completing a four-year college degree (i.e., 'college completion'), which consists of those who have earned a bachelor's degree or higher. For those who have positive years of college but did not complete a four-year degree, this indicator takes a value of zero. Those with no college education are excluded in this case. This variable allows us to isolate the intensive margin of college education, as everyone in the sample has some college education. Note that both education measures include those with post-graduate education. Our analysis, however, focuses on the extensive and intensive margins of undergraduate education.

Tables 3 and 4 show that the younger sample has slightly fewer years of education: 14.13 compared to 14.23. There is little difference between the two samples in terms of the percent who obtain some college, with 69 percent having at least one year of college education. The younger group has slightly lower college completion rates (at 34\% compared to $36 \%$ for the older group). Overall, the two age groups are quite similar in terms of educational attainment.

If endogeneity exists, it likely operates through income. Hence, in the second stage of the estimation, we include a binary variable for positive household earnings and the natural log of reported annual household earnings (in 2009 dollars) interacted with the binary variable for earnings: ${ }^{21}$ To control for demographic effects, we include sets of indicator variables for gender, race, and marital status, and controls for age, age-squared, and household size. As evident

\footnotetext{
${ }^{21}$ We do not include income as a control in the first-stage regression since the relationship between income and the probability of applying for a loan or credit card is unclear ex ante. Our results do not change if income is included in both stages, but the estimated coefficients for income are more noisy in the second stage.
} 
in Tables 3 and 4 , the demographics of the younger sample is slightly different from the older sample: the younger sample is more racially diverse, with a larger share of blacks and Hispanics, is less likely to be married, has a smaller household, and has slightly lower household earnings. In the second stage of the estimation, we also include a measure of aggregate college enrollment rates in the year when the respondent was 18 years old (which we refer to as the cohort year) ${ }^{22}$

Tables 3 and 4 also provide a glimpse of how credit status and educational attainment are related. Among people who applied for credit, those who have been turned down have lower educational attainment on average, and this trend is slightly more pronounced if the reported reason was having bad credit (compared to being turned down). In fact, respondents with bad credit status have lower college completion rates than those who applied for credit. The pattern is similar when we compare the educational attainment of all credit card holders to the schooling outcomes of people who hardly ever repay their credit card balance, and are consistent across both the young and old samples. These statistics are an indication that credit status may relate differently to the extensive and intensive margins of college investment. We explore this in more detail in Section 4. The summary statistics suggest that respondents with worse credit behavior are more likely to be female, black, Hispanic, single and have larger households. It is somewhat surprising that households with bad credit status do not report earnings much different from the rest of the sample (for those with positive earnings). In what follows, we will be able to identify the importance of the demographic factors when estimating the relationship between credit status and educational attainment.

\section{Empirical Results}

\subsection{Years of Educational Attainment}

We first start by estimating the effects of credit status on years of educational attainment. Recall that we use two samples of high school graduates based on age (age 23-30 and age 3140). By doing so, we can isolate the effect of credit status on college investment for young adults. In Table 5, we report the second stage of the Heckman results for the three different measures of credit status: having bad credit, being turned down for credit, and hardly ever repaying credit card balances. The dependent variable is the number of years of education. Recall that sample sizes vary across the different measures of credit status.

As evident in all six columns, having worse credit leads to less college education. Specifically, younger respondents with bad credit have 0.56 fewer years of education, while those being turned down for credit have 0.47 fewer years of education. For those who report to hardly ever repay their credit card balance, educational attainment is 0.56 years lower. For the older age

\footnotetext{
${ }^{22}$ Enrollment rates come from the BLS: http://www.bls.gov/opub/ted/2010/ted_20100428.htm
} 
group, the coefficients for bad credit and being turned down are smaller in magnitude than the younger group, but are still significant. However, the coefficients for 'hardly ever repay' are slightly larger. All of the estimated coefficients are significant at the $1 \%$ level. Overall, it seems as if having worse credit has a negative impact on years of educational attainment; this is robust across various measures of credit status and age groups ${ }^{23}$

The control variables have the expected signs. For example, for those with positive wages, higher household wage is correlated with more educational attainment. However, respondents who live in households with positive wages are likely to have less education. This arises because there are very few respondents in our sample with zero household wages. They may be atypical in that they are in school full-time or have other sources of income (such as business income or capital gains). By comparing the coefficients on the indicator for positive household wages and the natural logarithm of household wages, we find that educational attainment is lower for people whose household income is less than the mean (approximately $\$ 22,000$ ) compared to people with zero household earnings. Comparing the wage coefficients across age groups, we see that the estimates for the older age group are approximately twice as large as the younger group.

We also find that demographic variables are significantly correlated with educational attainment, consistent with the literature. Having a smaller household and being married are both positively (and significantly) correlated with educational attainment. Race is also important, with Hispanics and blacks having less education than whites (the comparison group). Most of these effects are significant at the $1 \%$ or $5 \%$ level, with similar signs and magnitudes across the three different credit measures. Our results indicate that the coefficients on Hispanics and blacks are smaller (or insignificant) for the younger group, indicating that differences in college attainment by race are shrinking over time (Seidman (2005)). Females are also less educated than males, but only significantly so in the older age group, which is consistent with the trends of increasing college enrollment and completion rates for women (Becker et al. (2010)).

We also consider if aggregate trends in college enrollment rates affect the relationship between credit status and education. Across credit measures and age groups, higher national college enrollment rates are positively associated with higher educational attainment. Importantly, controlling for aggregate effects does not change the negative relationship between having worse credit status and educational attainment in all three specifications. This suggests that the relationship is more than cyclical - we are documenting a relationship between credit status and education that holds up in different macroeconomic conditions.

As mentioned in Section 2, the first stage of the selection model attempts to control for any inherent selection bias that exists based on respondents' willingness to use credit. As such, the dependent variables are indicator variables for respondents who applied for a loan (for 'bad

\footnotetext{
${ }^{23}$ In Section 5 , we consider several other robustness checks.
} 
credit' and 'turned down') or who have at least one credit card (for 'hardly ever repay'). The regressors that are included in the first stage but excluded in the second stage are variables measuring respondents' attitudes towards borrowing in different circumstances. We also include the demographic controls in the first stage equation. We report the estimation results for the first stage in Table6. Note that the results from the first stage are identical for 'bad credit' and 'turned down' and are not reported for both. Many of the excluded variables are significantly correlated with the likelihood of applying for a loan and having a credit card. For example, in the younger group, those who shop around for credit and think using credit to buy a car is fine are more likely to have applied for a loan (in the first column, while those who think using credit to pay for a living expenses, fur coats, jewelry and to buy a car are more likely to have a credit card (in the second column). Similar results are reported for the older group (however, there is some variation in the significance of the estimated coefficients compared to the younger group). Overall, we are confident that the first stage estimation is helping to mitigate some of the sample selection biases. Note, however, that the estimated selection coefficient $\lambda$ is significant only for the younger group who have been turned down for credit, indicating that there may not be selection bias for all groups.

\subsection{College attainment}

It has been widely accepted in the literature that the decision to attend college is influenced by expected gains in lifetime earnings, which in turn are determined by unobservable characteristics such as human capital, ability, risk attitudes, etc. (Mincer (1974) and Willis and Rosen (1979)). We posit that credit status may be among the factors that are correlated with college attainment.

We analyze the extent to which credit status affects the decision to attain some college for all high school graduates ('college attainment'). The estimation consists of a linear probability model with binary dependent variable which takes a value of one when respondents have at least one year of college education. It takes a zero value if respondents have no college education (i.e., those with only 12 years of education). For ease of exposition, we report only the estimated coefficients on the credit measures in Table $7{ }^{24}$

Our results indicate that credit status is significantly associated with college attainment for the younger sample and this is robust across all three measures of credit status. Having bad credit leads to a 6.8 percentage point reduction in the likelihood of attaining some college. Being turned down for credit leads to a 4.9 percentage point reduction in the likelihood of attaining some college, while hardly ever repaying credit card balances lowers attainment rates

\footnotetext{
${ }^{24}$ The full set of results, including those from other empirical specifications not mentioned here, can be obtained from the authors' online appendix available at http://www.uncg.edu/bae/people/gicheva/onlineappendix.pdf
} 
by 7.8 percentage points. Credit status seems to be a robust predictor of attaining some college, but only for the young sample. For the older sample, only respondents who hardly ever repay their credit card balances experience a significant reduction in the likelihood of attaining some college. Neither bad credit nor being turned down have a significant effect on attaining some college (however, the signs remain negative). We will document (in Section 5) that endogeneity is likely an issue for the older sample, which leads to inconsistent predictors for this group.

The coefficients for Hispanics in the older sample (not shown in Table 7) are large in absolute value and significant, whereas in the young sample none of the race indicators are significant. This suggests that the Hispanic control variable could be soaking up much of the variation in the likelihood of attaining some college for the older group, which may lead to insignificant coefficients on two of the credit measures. Alternatively, it could be due to the fact that more Hispanics are going to college in recent years but dropping out of college at relatively high rates (Seidman (2005)). We believe that the inclusion of the race indicators is important as they are significant in most of the empirical specifications and thus are important predictors of college investment in general (Cameron and Heckman (2001), Black and Sufi 2002); Light and Strayer (2002); Turner (2004); Krueger et al. (2006)).

The other control variables have similar signs and significance as in Table 5. The main difference is that the race and married indicator variables are no longer significant in the younger sample. Still, the inclusion of these controls (with the exception of race for the older sample) does not change the significance of the robust relationship between credit status and attaining some college.

In the first stage of estimation (in Table 8), we find evidence that negative selection bias exists for two of the credit measures in the younger sample, as evidenced by the significant and negative $\lambda$ for those with bad credit and who were turned down for credit. In addition, our results suggest that the error terms $(\rho)$ are negatively correlated with attaining some college for the younger group but not the older group. A negative $\rho$ may be indicative of some unobserved heterogeneity: people who are more likely to need or want credit in their twenties are also less likely to attain some college, perhaps because they are less financially responsible. For the older age group, applying for credit may not necessarily mean they are being financially irresponsible if the loan is to buy a house, for example. Thus, we do not observe a negative correlation in error terms for the older group ( $\rho$ is small but positive for all three credit measures with no significant amount of selection bias). In general, the selection model seems warranted since at least some sub-samples have selection bias. However, our results are robust to simpler specifications that do not account for selection bias, such as OLS, indicating that the selection bias is not large enough to lead to inaccurate conclusions. 


\subsection{College completion}

We next attempt to isolate the effects of credit status on the intensive margin of college education, namely, the likelihood of completing a bachelor's (i.e., four-year) degree. In this case, the sample is restricted to respondents who have at least one year of college education. ${ }^{25}$ The estimation consists of a linear probability model with the dependent variable taking a value of one if the respondent has completed a four-year college degree; respondents with two-year degrees are categorized as having some college and hence take a zero value for having completed a four-year degree, as do respondents currently enrolled in college and drop-outs. Table 7 reports the results. Note that those with a college degree includes those with post-graduate education.

Our results indicate that credit status has a significant effect on completing a four-year college degree. In fact, the estimated coefficients are quite large. Young respondents with bad credit, for example, are 17.2 percentage points less likely to have a college degree than those with good credit. Being turned down for credit and hardly ever repaying credit card balance reduces the likelihood of having a college degree by 15.3 percentage points. Similar magnitudes are found for the older group, with all point estimates being significant at the $1 \%$ level. This contrasts to the results for some college attainment, which were less robust for the older sample. Importantly, the effects of credit status on college completion are much larger than the effects on attaining some college (Table 7). Thus, credit status has an economically and statistically significant effect on having a four-year college degree, and this effect is larger than the effect on having some college; it is also robust across credit measures and age groups. To date, this has not been documented in the existing literature and perhaps is our most important new finding.

We add to the literature on the determinants of college investment that suggests skills, ability and human capital acquisition are far more important for college completion than attaining some college (Cameron and Taber (2001), Carneiro and Heckman (2002), Cunha and Heckman (2009), and Stinebrickner and Stinebrickner (2009)). An important observation in recent literature is that college investment is risky (see Restuccia and Urrutia (2004), Garriga and Keightley (2007), Johnson (2010) and Chatterjee and Ionescu (2011)). College preparedness and effort during college are ways of mitigating that risk and hence serve as important determinants of college completion (Manski (1983), Cunha et al. (2005), Cunha and Heckman (2009), Stinebrickner and Stinebrickner (2009), Bound et al. (2010) and Ionescu (2011)). Credit status may be one measure of some of the unobserved risk in college students. In addition, worse credit status may tighten credit constraints, making it less likely for college-going students to complete college. Perhaps declining credit status of college-going students could be part of the explanation behind declining college completion rates, as documented in Turner (2004) and Bound et al. (2010), for example. Either way, our results suggest that credit status should be listed among the

\footnotetext{
${ }^{25}$ Recall that since the sample consists of young adults, we are missing those who complete a college degree later in life (after age 40).
} 
factors that affect college completion. We do not find any evidence of selection bias (negative or positive) for either age group (reported in Table 8). The inclusion of the control variables does not change the significance of the relationship between credit status and college completion rates (the full set of results is available in the authors' online appendix).

Overall, we find an economically significant relationship between credit status and college completion and a significant but smaller effect of credit status on attaining some college. Thus, our main result is that credit status matters more for college investment the longer students are in college. This makes sense, as the evidence suggests that students first turn to more typical resources to finance college early on, such as parental contributions, student's savings, and government student loan programs. As those funds become depleted, students turn to other forms of credit to finance their college education, such as the private student loan market or credit cards. In both cases, credit status is the primary determinant of eligibility, credit

availability and the price of credit. As such, having worse credit makes these funds more costly, or worse yet, unavailable, making college investment more difficult. Given that we find a positive relationship between credit status and educational attainment, it is plausible that if students could not access unsecured credit markets to finance college (due to bad credit status), some college students may in fact be credit-constrained. If so, our results indicate that financial constraints more likely bind later in the college investment process rather than at the beginning.

\section{Robustness}

Using a Heckman two-step model that controls for selection bias, we find that credit status matters more for college completion than for attaining some college. We demonstrated above that this result is robust across three different measures of credit status and two age groups of young adults. We also controlled for demographic characteristics, wages, aggregate enrollment rates and various measures of respondents' attitudes towards credit. In this section, we consider several other empirical specifications and compare them to our baseline results (in Table 7 ). All estimates that are not reported in the paper are available in the online appendix.

\subsection{Year Fixed Effects and Timing}

Certainly, the landscape for credit markets changed during this time period (1995 to 2007), and perhaps the changing landscape contributed to changes in college enrollment and completion rates. To account for unobserved time-specific factors that could affect the credit statuseducation relationship, we introduce time fixed effects. That is, we include a set of indicator variables for each survey year in both the first and second stage of estimation. The results are reported in Table 9, When comparing these results to the baseline results in Table 7, all of the 
estimated coefficients are nearly identical in size and are exactly the same in terms of sign and significance across all three credit measures and the two age groups. Thus, all of our results are robust to the inclusion of time fixed effects.

Similarly, we can exploit the long time span of the SCF to see if the relationship between credit status and education has changed over time. We create a dummy variable for the cohorts of respondents who were 18 years old in 1999 or later. According to College Board (2011), nonfederal student loans increased dramatically in the 1999-2000 academic year (by 26\%), making it a relevant turning point in the student loan market. We interact this cohort dummy with the various credit measures to see if, for example, the availability of private student loans has led to a stronger credit status-education relationship in recent years. The negative, insignificant coefficients on the interaction term suggests that the negative relationship between bad credit status and educational attainment may be in fact stronger in recent years. Importantly, the coefficients of interest (on the credit measures) are very similar to the baseline results.

The cross-section nature of the SCF data makes it difficult to pin down the relationship between credit status and educational attainment over time. We observe the current credit status of people and try to determine if that has a causal effect on college attainment. Our implicit assumption is that the credit status of young households is constant and unaffected by educational attainment at this stage of their lives. In the next subsection, we try to isolate the direction of the causality.

\subsection{Endogeneity}

As discussed above, endogeneity may be an issue. Given that an appropriate instrument has not been identified, we have attempted to deal with the endogeneity in several ways.

In the baseline case, we report separate results for the younger age group from the older age group, since endogeneity may be a larger issue for the older age group given that there has been more time for educational attainment to affect credit status through income. We also control for household earnings, which should help to mitigate this problem. Given that the older group did not have access to the private market for college loans, it should be that the effect of credit status on college investment is weaker for this group. We found smaller, but significant, effects for the older group. If endogeneity is a problem for the older group, then the estimated coefficients may not be meaningful at all.

As an alternative way of getting at any possible endogeneity, we omit the income controls from all of the regressions. By removing the income controls, the endogeneity problem, if it

exists, should get worse since endogeneity in this case will likely work through income (more college education leads to more income which leads to better credit status). That is, the coefficients on the credit measures should become more negative due to omitted variable bias 
because the credit variables would be picking up part of the income effect. The results in Table 10 report the baseline regressions but remove the indicator for household wages and the interaction term between that indicator and the natural logarithm of household wages.

We find that the coefficients on 'turned down' in the years of education regressions changes from -0.470 (in the baseline) to -0.519 for the younger group and from -0.309 to -0.519 for the older group - clearly the second change is bigger in absolute and especially in percentage terms. The same is true for the coefficients on the 'bad credit' and 'hardly ever repay' measures. For those who have attained some college, the coefficient on 'turned down' for the younger group changes from -0.049 to -0.057 (both of which are significant); for the older group, the coefficient goes from -0.014 to -0.048 and now becomes significant. The change in the coefficients is much larger for the older group, where we claim that the endogeneity problem should be more severe. The same comparison can be made for the college completion results, but the relative change in the coefficients as a result of omitting the income variables is smaller across both age groups. But still the older age group experiences larger increases in the estimated coefficients (in absolute value terms) when the income variables are omitted.

Since the coefficients do not change much for the younger group and change more for the older group, this suggests that if endogeneity is a problem, it is more severe for the older group. Obviously controlling for income does not pick up all of the possible interactions between education, income and credit status (i.e., there may be other sources of endogeneity), but it certainly helps to mitigate the endogeneity issues. Our main results are also robust to controlling for employment status (full-time or part-time) and the previous year's pre-tax income (in addition to current year labor earnings) ${ }^{26}$ This helps us feel comfortable that while endogeneity may be an issue (and particularly for the older sample), it is not driving all of our findings.

In addition, by omitting the income variables, the mixed results we found for the older group with some college attainment become more consistent. Notice that for those with some college attainment, both bad credit and turned down are now significantly and negatively correlated with attaining some college (in the baseline, they were insignificant). This suggests that endogeneity may be driving some of the results for the older group, and the documented effects for this group should be taken with grain of salt. Still, even if credit status and college investment are endogenous, our analysis suggests that the relationship likely works both ways, and that later in life, college investment may have some important effects on credit status.

\subsection{Alternative Credit Measures}

We consider some alternative measures of credit status that are available in the SCF. We consider if respondents have missed a payment on any sort of loan or had a late payment

\footnotetext{
${ }^{26}$ These results are available in the authors' online appendix.
} 
over the last year ('missed payment'), if they have filed for bankruptcy ${ }^{27}$, and the ratio of the respondent's balance on their credit cards relative to their credit limit as alternative measures of having bad credit ('balance/limit'). All three indicators signify worse credit status if they take the value of one. The results are reported in Table 11 for both age groups. All of the new credit measures have similar relationships with college investment as the measures we use in the baseline specification, with the exception of the balance-limit ratio for the older group (that is not related to any type of college investment). It is likely that older cohorts have more non-education related expenses that drive up their credit card balances. Overall, we find a negative and significant relationship between several different measures of bad credit status and college investment.

\subsection{Other Sub-Samples and Empirical Specifications}

Next, we estimate our baseline specifications for other, more narrow, samples of the population. For brevity, we report these and many other robustness checks in our online appendix. First we drop those who are currently enrolled in college ${ }^{28}$ Our results are nearly identical to our baseline results, where credit status is significantly associated with years of college education and college completion rates for both age groups, but is not significantly related the likelihood of attaining some college for the older group.

We then consider only those who are single and those who with a household size of one (indicating that they are single without dependents). We do this because many of the SCF credit variables are household- rather than individual-specific. In the case of married households, the respondent's credit status (from which most of the independent variables are derived from) may be different from the the credit status of the household. Once again, all of the results are similar as before but now we find a slightly weaker relationship between credit status and attaining some college than in our baseline (with less statistical significance on the various credit measures for both age groups). The sample sizes in these cases are quite small, but we still document an important relationship between credit status and college investment.

Finally, we consider a simpler specification by first estimating the baseline specification using OLS for our sample of those who have applied for a loan/credit card. We then include those who have not applied for a loan or do not have a credit card classifying them as having poor credit status (that is, no credit is equivalent to having bad credit) in an OLS specification. Note that neither of these specifications control for sample selection bias. The OLS results for our sample are very similar to the results in Table 7 in terms of signs and significance, but all of the point estimates are slightly larger in absolute value than with the selection model,

\footnotetext{
${ }^{27}$ These data were not available in the 1995 survey.

${ }^{28}$ We use the SCF variables x4100 and x4700 to identify respondents who are students.
} 
confirming our suspicions that the selection bias is positive. For the sample that includes those without credit status, the results are also robust and even a little stronger for the older age group (especially for attaining some college).

\section{Conclusion}

This paper is the first to analyze how credit status affects college investment in an empirical framework. Given recent trends in using both the private market for student loans and other forms of unsecured credit (such as credit cards) to finance college, it is plausible that an individual's credit status may distort the college decision. Our empirical results suggest that it does. Using data from the Survey of Consumer Finances (SCF), we find that credit status affects both the likelihood of enrolling in college and completing college. However, the effects on college completion are larger, indicating that credit status is more important the longer a student is in college. Our results indicate that young adults (age 18-30) who report to have bad credit are 17.2 percentage points less likely to complete a four-year college degree than those who do not have bad credit. This compares to the percent of people attaining some college being 6.8 percentage points lower for those with bad credit.

We document that our results are robust to different sets of control variables, including demographic and aggregate trends, and a multitude of sub-samples of the data. We focus on young adults to minimize the endogeneity problem and control for the selection bias using a Heckman selection model. We incorporate various measures of credit status from the SCF data, all of which yield similar results.

Credit status could be used to determine the extent to which college-going students are credit-constrained. Our findings hint at the possibility that students with worse credit status may find it more difficult to complete college since they may experience tighter credit markets (both with less access to these markets and higher prices to participate). With the widespread use of credit cards by college students and more participation in the private markets for student loans, this effect may at least partially explain the declining college completion rates in the U.S. in recent years when credit markets tightened up and individual credit statuses worsened.

We believe this paper represents a starting point on a topic that has so far been ignored. The SCF data are rich with respect to information about credit usage and status, but does not contain much detail about the college experience. Other datasets produced by the US Department of Education (such as HS\&B:92 and BPS:04/09) may be useful in analyzing this topic since they contain more information about the college experience and have some information about credit status. Our results are more applicable to independent students, but the credit status-college investment relationship may vary for dependent versus independent college students. For dependent students, the credit status of parents may matter for college invest- 
ment, which in turn could affect the credit status of the student. In fact, how credit status is transferred across generations via college investment may be particularly interesting. Additionally, we have focused on undergraduates but the impact of credit status may be even larger for graduate students who use the private market for student loans at higher rates. Certainly, educational outcomes, which have large documented effects on lifetime income, will affect credit status over time; our results imply that this may be more relevant as people get older. Very little has been done analyzing the effect of educational attainment on credit status (with the exception of perhaps Athreya et al. (2012)). We leave these questions (and many more) for future work. Our analysis represents a starting point for a new line of research that will be increasingly important as students continue to use credit markets to finance part of their college education. 


\section{References}

Akyol, A. and K. Athreya (2005). Risky Higher Education and Subsidies. Journal of Economic Dynamics and Control 29(6), 979-1023. 11

Athreya, K., X. Tam, and E. Young (2012). A Quantitative Theory of Information and Unsecured Credit. American Economic Journal: Macroeconomics, Forthcoming. 6]

Becker, G., W. Hubbard, and K. Murphy (2010). Explaining the Worldwide Boom in Higher Education of Women. Journal of Human Capital 4 (3), 203-241. 4.1

Becker, G. and N. Tomes (1979). An Equilibrium Theory of the Distribution of Income and Intergenerational Mobility. Journal of Political Economy 87(6), 1153. 1.1

Black, S. and A. Sufi (2002). Who Goes to College? Differential College Enrollment by Race and Family Background. NBER Working Paper 9310. 4.2

Bound, J., M. Lovenheim, and S. Turner (2010). Why Have College Completion Rates Declined: Marginal Students or Marginal College? American Economic Journal: Applied Economics, 129-157. 4.3

Brown, M., A. Haughwout, D. Lee, and W. van der Klaauw (2011). Do We Know What We Owe? A Comparison of Borrower- and Lender-reported Consumer Debt. Federal Reserve Bank of New York Staff Report no. 523. 3

Brown, M., A. Haughwout, D. Lee, W. van der Klaauw, and M. Mabutas (2012). Grading Student Loans. Liberty Street Economics, Federal Reserve Bank of New York. 1

Brown, M., J. Scholz, and A. Seshadri (2009). A New Test of Borrowing Constraints for Education. NBER Working Paper 14879. 1.1

Cameron, S. and J. Heckman (1998). Life Cycle Schooling and Dynamic Selection Bias: Models and Evidence for Five Cohorts of American Males. Journal of Political Economy 106(2), 262-333. 10

Cameron, S. and J. Heckman (2001). The Dynamics of Educational Attainment for Black, Hispanic, and White Males. Journal of Political Economy 109(3), 455-499. 10, 4.2

Cameron, S. and C. Taber (2001). Borrowing Constraints and the Returns to Schooling. NBER Working Paper 7761. 4.3

Cameron, S. and C. Taber (2004). Estimation of Educational Borrowing Constraints using Returns to Schooling. Journal of Political Economy 112(1), 132-182. 1.1, 10 
Carneiro, P. and J. Heckman (2002). The Evidence on Credit Constraints in Post-Secondary Schooling. The Economic Journal 112(482), 705-734. 1.1, $10,4.3$

Chatterjee, S. and F. Ionescu (2011). Insuring College Failure Risk. Federal Reserve Bank of Philadelphia Working Paper. 4.3

College Board (2006). Trends in Student Aid. College Board Publication. 1

College Board (2011). Trends in Student Aid. College Board Publication. 1, 5.1

Cunha, F. and J. Heckman (2009). The Economics and Psychology of Inequality and Human Development. Journal of the European Economic Association 7(2-3), 320-364. 4.3

Cunha, F., J. Heckman, and S. Navarro (2005). Separating Uncertainty from Heterogeneity in Life Cycle Earnings. Oxford Economic Papers 57(2), 191-261. 4.3

Dynarski, S. (2002). Loans, Liquidity, and Schooling Decisions. Kennedy School of Government Working Paper. 11

Dynarski, S. (2003). Does Aid Matter? Measuring the Effect of Student Aid on College Attendance and Completion. American Economic Review 93, 279-288. 11

Dynarski, S. (2005). Finishing College: the Role of State Policy in Degree Attainment. Kennedy School of Government Working Paper. 11

Gallup and Sallie Mae (2008). How America Pays for College. Sallie Mae's National Study of College Students and Parents. 1, 1.1

Garriga, C. and M. Keightley (2007). A General Equilibrium Theory of College with Education Subsidies, In-School Labor Supply, and Borrowing Constraints. Federal Reserve Bank of St. Louis Working Paper, 207-051. 11, 4.3

Institute for Higher Education Policy (2006). The Future of Private Loans: Who is Borrowing, and Why? Working paper. 3

Ionescu, F. (2009). Federal Student Loan Program: Quantitative Implications for College Enrollment and Default Rates. Review of Economic Dynamics 12(1), 205-231. 11

Ionescu, F. (2011). Risky Human Capital and Alternative Bankruptcy Regimes for Student Loans. Journal of Human Capital 5(2), 153-206. 4.3

Ionescu, F. and N. Simpson (2011). Credit Scores and College Investment: Implications for Student Loan Policies. Colgate University Working Paper. 1.1 
Johnson, M. (2010). Borrowing Constraints, College Enrollment, and Delayed Entry. Mathematica Policy Research Working paper. $11,4.3$

Kane, T. (2003). A Quasi-Experimental Estimate of the Impact of Financial Aid on CollegeGoing. National Bureau of Economic Research Working Paper 9703. 11

Keane, M. and K. Wolpin (2001). The Effect of Parental Transfers and Borrowing Constraints on Educational Attainment. International Economic Review 42(4), 1051-1103. 10

Kennickell, A. (1998). Multiple Imputation in the Survey of Consumer Finances. Proceedings of the Section on Business and Economic Statistics. 14

Krueger, A., J. Rothstein, and S. Turner (2006). Race, Income, and College in 25 Years: Evaluating Justice O'Connor's Conjecture. American Law and Economics Review 8(2), 282311. 4.2

Light, A. and W. Strayer (2002). From Bakke to Hopwood: Does Race Affect College Attendance and Completion? Review of Economics and Statistics 84 (1), 34-44. 4.2

Lochner, L. and A. Monge-Naranjo (2011). Credit constraints in education. American Economic Review 101(6), 2487-2529. 1.1

Manski, C. (1983). College Choice in America. Harvard University Press. 4.3

Mincer, J. (1974). Schooling, Experience, and Earnings. Human Behavior \& Social Institutions No. 2. National Bureau of Economic Research. 4.2

Restuccia, D. and C. Urrutia (2004). Intergenerational Persistence of Earnings: The Role of Early and College Education. American Economic Review 94(5), 1354-1378. 4.3

Sallie Mae (2009). How Undergraduate Students Use Credit Cards: Sallie Mae's National Study of Usage Rates and Trends. Technical report. 1, 13,

Seidman, A. (2005). College student retention: Formula for student success. Greenwood Publishing Group. 4.1, 4.2

Steele, P. and S. Baum (2009). How Much are College Students Borrowing? College Board Policy Brief. 1

Stinebrickner, R. and T. Stinebrickner (2008). The Effect of Credit Constraints on the College Drop-Out Decision: A Direct Approach Using a New Panel Study. American Economic Review 98(5), 2163-2184. 1.1 
Stinebrickner, T. and R. Stinebrickner (2009). Learning about Academic Ability and the College Drop-out Decision. NBER Working Paper 14810. 4.3

The Education Resources Institute, Inc. (1998). Credit Risk or Credit Worthy? College Students and Credit Cards. Working paper. 8

Turner, S. (2004). Going to College and Finishing College. Explaining Different Educational Outcomes. The University of Chicago Press, Chicago. 1.1, 11, 4.2, 4.3

Wei, C., S. Nevill, and L. Berkner (2005). Independent Undergraduates: 1999-2000. US Department of Education. Washington, DC: National Center for Educational Statistics, NCES 2005-151. 1

Willis, R. and S. Rosen (1979). Education and Self-Selection. Journal of Political Economy $87(\mathrm{~S} 5), 7.4 .2$ 


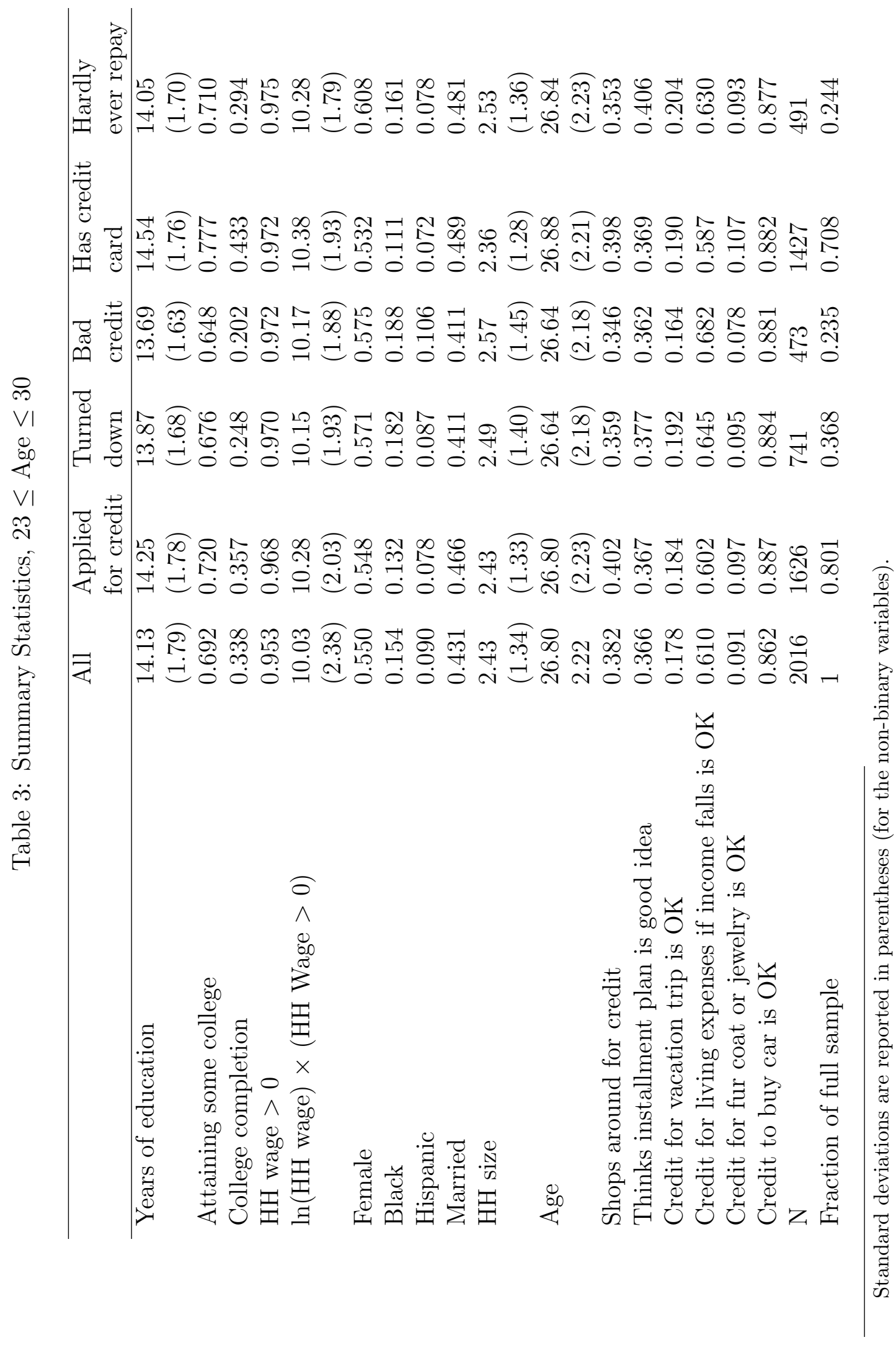




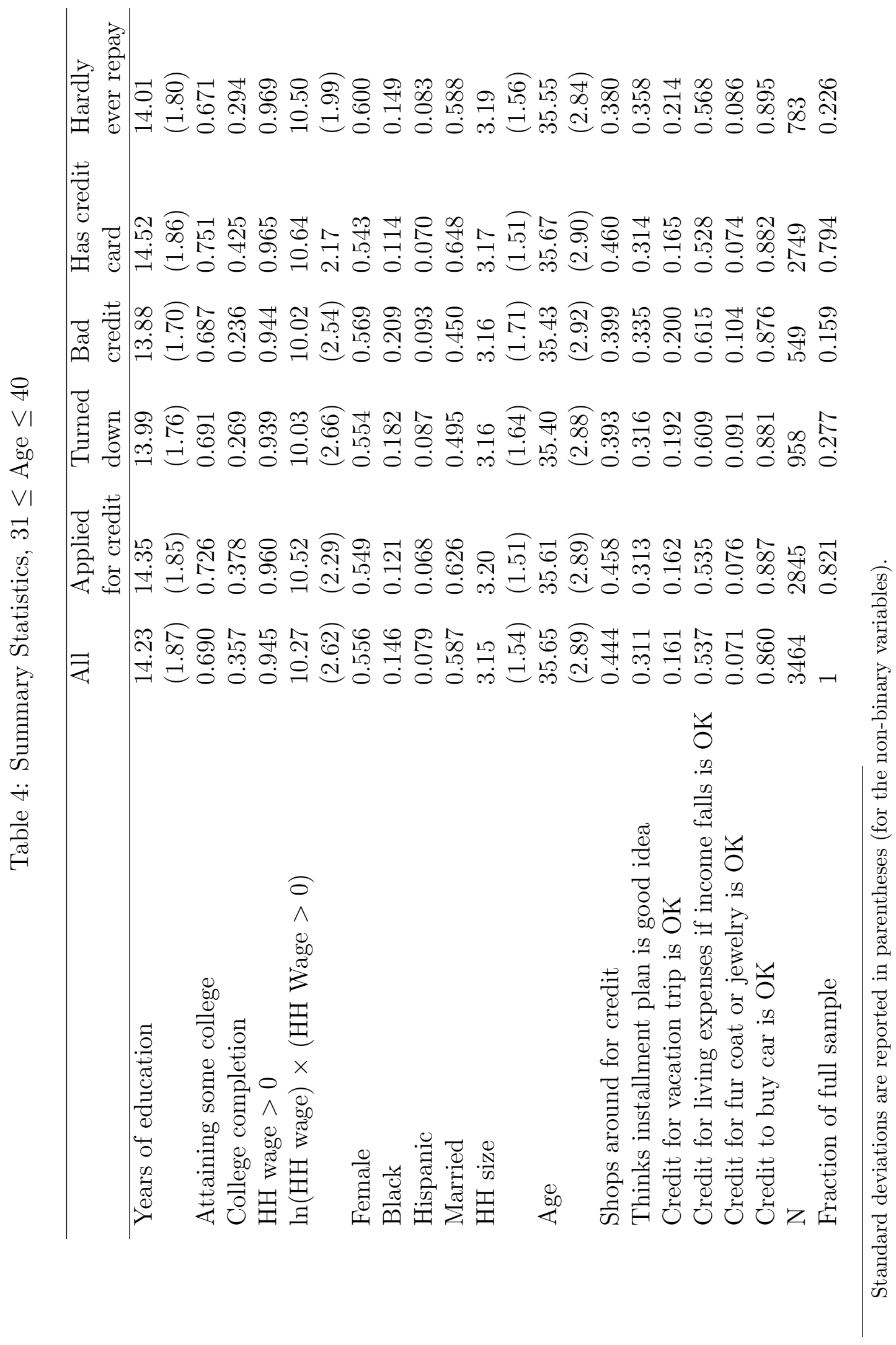




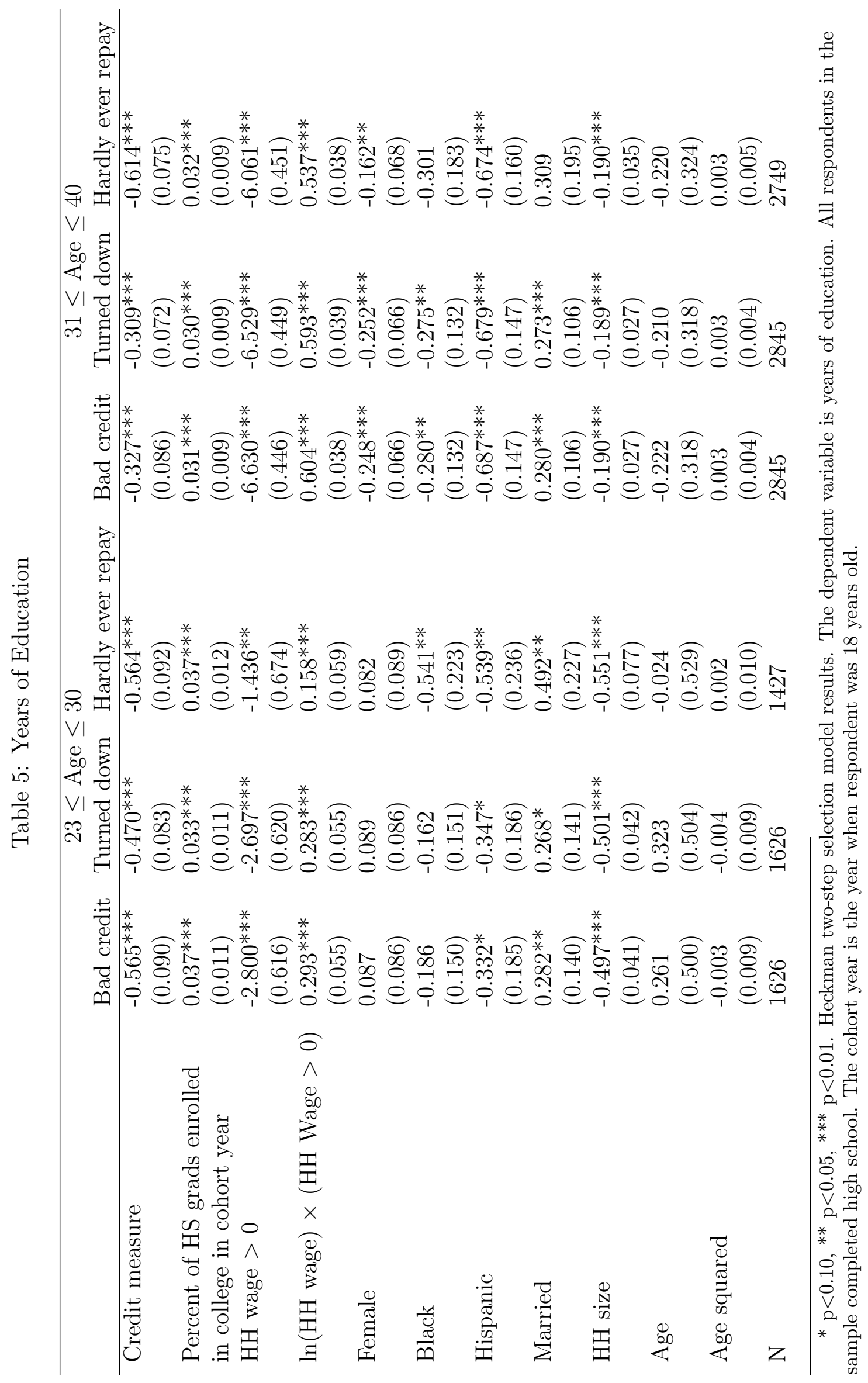




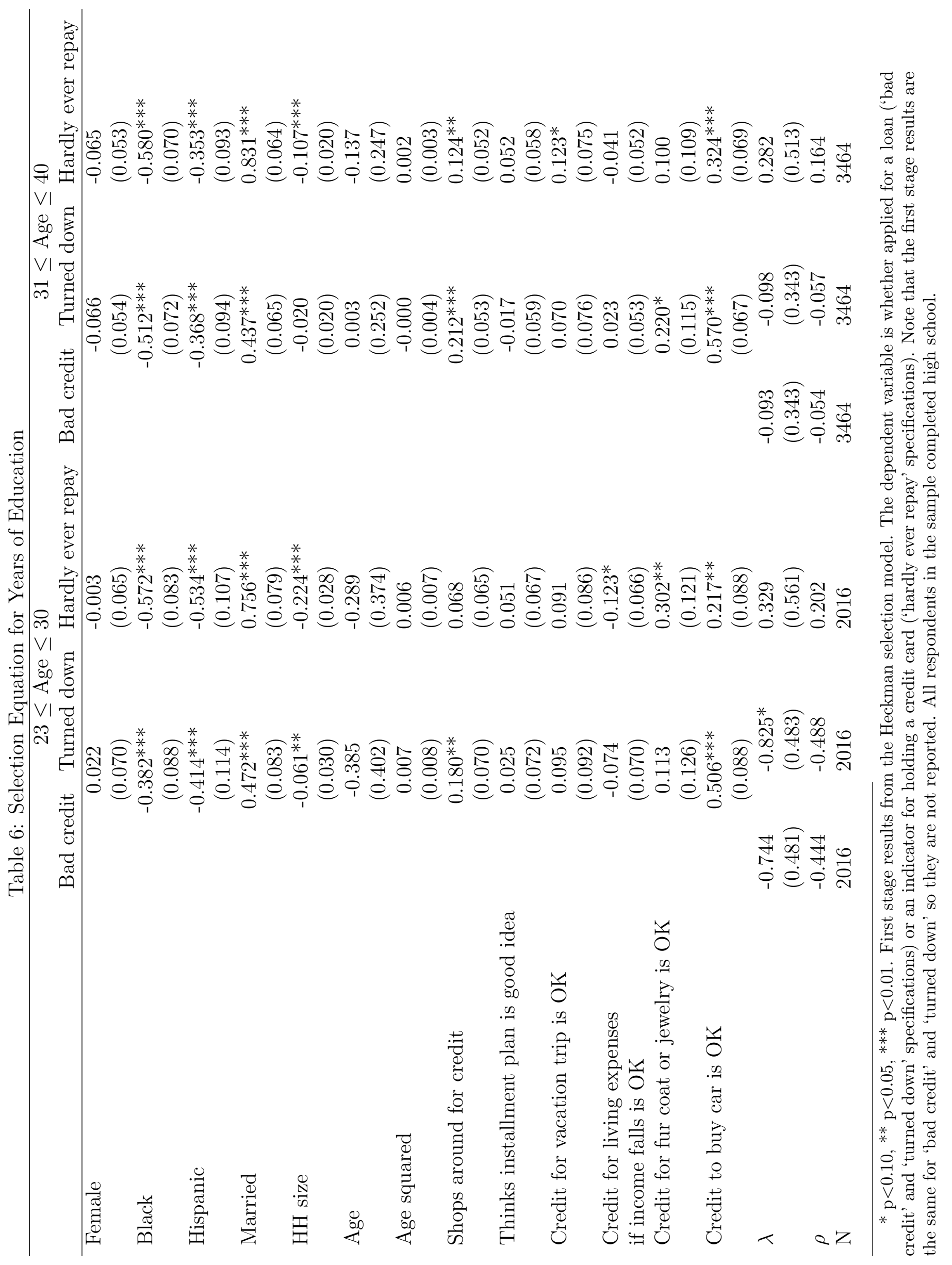


Table 7: Baseline Results

$$
23 \leq \text { Age } \leq 30 \quad 31 \leq \text { Age } \leq 40
$$

Bad credit Turned down Hardly ever repay Bad credit Turned down Hardly ever repay

\begin{tabular}{|c|c|c|c|c|c|}
\hline \multicolumn{6}{|c|}{ Years of Education } \\
\hline $\begin{array}{l}-0.565^{* * *} \\
(0.090)\end{array}$ & $\begin{array}{l}-0.470^{* * *} \\
(0.083)\end{array}$ & $\begin{array}{l}-0.564^{* * *} \\
(0.092)\end{array}$ & $\begin{array}{l}-0.327^{* * *} \\
(0.086)\end{array}$ & $\begin{array}{l}-0.309 * * * \\
(0.072)\end{array}$ & $\begin{array}{l}-0.614^{* * *} \\
(0.075)\end{array}$ \\
\hline \multicolumn{6}{|c|}{ Attaining Some College } \\
\hline $\begin{array}{l}-0.068^{* * *} \\
(0.024)\end{array}$ & $\begin{array}{l}-0.049^{* *} \\
(0.022)\end{array}$ & $\begin{array}{l}-0.078^{* * *} \\
(0.023)\end{array}$ & $\begin{array}{l}-0.008 \\
(0.021)\end{array}$ & $\begin{array}{l}-0.014 \\
(0.018)\end{array}$ & $\begin{array}{l}-0.105^{* * *} \\
(0.018)\end{array}$ \\
\hline \multicolumn{6}{|c|}{ College Completion } \\
\hline $\begin{array}{l}-0.172^{* * *} \\
(0.031)\end{array}$ & $\begin{array}{l}-0.153^{* * *} \\
(0.028)\end{array}$ & $\begin{array}{l}-0.153^{* * *} \\
(0.030)\end{array}$ & $\begin{array}{l}-0.145^{* * *} \\
(0.027)\end{array}$ & $\begin{array}{l}-0.133^{* * *} \\
(0.023)\end{array}$ & $\begin{array}{l}-0.143^{* * *} \\
(0.024)\end{array}$ \\
\hline
\end{tabular}

${ }^{*} \mathrm{p}<0.10,{ }^{* *} \mathrm{p}<0.05,{ }^{* * *} \mathrm{p}<0.01$.

Table 8: Selection Bias in Heckman Two-Step Model

$23 \leq$ Age $\leq 30 \quad 31 \leq$ Age $\leq 40$

Bad credit Turned down Hardly ever repay Bad credit Turned down Hardly ever repay

\begin{tabular}{|c|c|c|c|c|c|c|}
\hline \multicolumn{7}{|c|}{ Years of Education } \\
\hline$\lambda$ & -0.744 & $-0.825^{*}$ & 0.329 & -0.093 & -0.098 & 0.282 \\
\hline$\rho$ & -0.444 & -0.488 & 0.202 & -0.054 & -0.057 & 0.1636 \\
\hline \multicolumn{7}{|c|}{ Attaining Some College } \\
\hline$\lambda$ & $-0.285^{* *}$ & $-0.296^{* *}$ & -0.165 & 0.005 & 0.005 & 0.033 \\
\hline$\rho$ & -0.616 & -0.636 & -0.396 & 0.012 & 0.012 & 0.082 \\
\hline \multicolumn{7}{|c|}{ College Completion } \\
\hline$\lambda$ & -0.098 & -0.097 & 0.317 & -0.087 & -0.089 & -0.070 \\
\hline$\rho$ & -0.213 & -0.210 & 0.639 & -0.188 & -0.194 & -0.154 \\
\hline
\end{tabular}

$\lambda$ is the estimated selection coefficient, and $\rho$ is the correlation coefficient for the error terms. $* \mathrm{p}<0.10,{ }^{* *} \mathrm{p}<0.05, * * * \mathrm{p}<0.01$.

Table 9: Baseline Specifications with Year Fixed Effects

\section{$23 \leq$ Age $\leq 30 \quad 31 \leq$ Age $\leq 40$}

Bad credit Turned down Hardly ever repay Bad credit Turned down Hardly ever repay

\begin{tabular}{|c|c|c|c|c|c|}
\hline \multicolumn{6}{|c|}{ Years of Education } \\
\hline $\begin{array}{l}-0.569 * * * \\
(0.090)\end{array}$ & $\begin{array}{l}-0.478^{* * *} \\
(0.083)\end{array}$ & $\begin{array}{l}-0.558^{* * *} \\
(0.092)\end{array}$ & $\begin{array}{l}-0.328^{* * *} \\
(0.086)\end{array}$ & $\begin{array}{l}-0.311 * * * \\
(0.072)\end{array}$ & $\begin{array}{l}-0.612^{* * *} \\
(0.075)\end{array}$ \\
\hline \multicolumn{6}{|c|}{ ttaining Some College } \\
\hline $\begin{array}{l}-0.069^{* * *} \\
(0.0239)\end{array}$ & $\begin{array}{c}-0.052^{* *} \\
(0.0221)\end{array}$ & $\begin{array}{l}-0.077^{* * *} \\
(0.0229)\end{array}$ & $\begin{array}{l}-0.009 \\
(0.021)\end{array}$ & $\begin{array}{l}-0.014 \\
(0.018)\end{array}$ & $\begin{array}{l}-0.105^{* * *} \\
(0.018)\end{array}$ \\
\hline \multicolumn{6}{|c|}{ College Completion } \\
\hline $\begin{array}{l}-0.173^{* * *} \\
(0.031)\end{array}$ & $\begin{array}{l}-0.157^{* * *} \\
(0.028)\end{array}$ & $\begin{array}{l}-0.153^{* * *} \\
(0.030)\end{array}$ & $\begin{array}{l}-0.146^{* * *} \\
(0.027)\end{array}$ & $\begin{array}{l}-0.133^{* * *} \\
(0.023)\end{array}$ & $\begin{array}{l}-0.143^{* * *} \\
(0.024)\end{array}$ \\
\hline
\end{tabular}

\footnotetext{
${ }^{*} \mathrm{p}<0.10,{ }^{* *} \mathrm{p}<0.05,{ }^{* * *} \mathrm{p}<0.01$. Baseline specification with survey year indicators in first and second stage.
} 
Table 10: Baseline Specifications Excluding Earnings

$$
23 \leq \text { Age } \leq 30 \quad 31 \leq \text { Age } \leq 40
$$

Bad credit Turned down Hardly ever repay Bad credit Turned down Hardly ever repay

\begin{tabular}{|c|c|c|c|c|c|}
\hline \multicolumn{6}{|c|}{ Years of Education } \\
\hline $\begin{array}{l}-0.600^{* * *} \\
(0.091)\end{array}$ & $\begin{array}{l}-0.519^{* * *} \\
(0.083)\end{array}$ & $\begin{array}{l}-0.591^{* * *} \\
(0.092)\end{array}$ & $\begin{array}{l}-0.519^{* * *} \\
(0.088)\end{array}$ & $\begin{array}{l}-0.519^{* * *} \\
(0.074)\end{array}$ & $\begin{array}{l}-0.797 * * * \\
(0.077)\end{array}$ \\
\hline \multicolumn{6}{|c|}{ Attaining Some College } \\
\hline $\begin{array}{l}-0.073^{* * *} \\
(0.024)\end{array}$ & $\begin{array}{l}-0.057^{* * *} \\
(0.022)\end{array}$ & $\begin{array}{l}-0.082^{* * *} \\
(0.023)\end{array}$ & $\begin{array}{c}-0.039^{*} \\
(0.021)\end{array}$ & $\begin{array}{l}-0.048^{* * *} \\
(0.018)\end{array}$ & $\begin{array}{l}-0.132^{\text {*** }} \\
(0.018)\end{array}$ \\
\hline \multicolumn{6}{|c|}{ College Completion } \\
\hline $\begin{array}{l}-0.192^{* * *} \\
(0.032)\end{array}$ & $\begin{array}{l}-0.175^{* * *} \\
(0.028)\end{array}$ & $\begin{array}{l}-0.166^{* * *} \\
(0.030)\end{array}$ & $\begin{array}{l}-0.191^{* * *} \\
(0.028)\end{array}$ & $\begin{array}{l}-0.176^{* * *} \\
(0.023)\end{array}$ & $\begin{array}{l}-0.178^{* * *} \\
(0.024)\end{array}$ \\
\hline
\end{tabular}

${ }^{*} \mathrm{p}<0.10,{ }^{* *} \mathrm{p}<0.05, * * * \mathrm{p}<0.01$.

Table 11: Alternative Measures of Credit Status

$23 \leq$ Age $\leq 30 \quad 31 \leq$ Age $\leq 40$

Missed payment Bankruptcy Balance/Limit Missed payment Bankruptcy Balance/Limit

\begin{tabular}{|c|c|c|c|c|c|c|}
\hline \multicolumn{7}{|c|}{ Years of Education } \\
\hline & $\begin{array}{l}-0.468^{* * *} \\
(0.091)\end{array}$ & $\begin{array}{l}-0.764^{* * *} \\
(0.187)\end{array}$ & $\begin{array}{l}-0.330^{* * *} \\
(0.089)\end{array}$ & $\begin{array}{l}-0.377^{* * *} \\
(0.078)\end{array}$ & $\begin{array}{l}-0.835^{* * *} \\
(0.114)\end{array}$ & $\begin{array}{l}-0.006 \\
(0.017)\end{array}$ \\
\hline $\mathrm{N}$ & 1653 & 1541 & 1427 & 3011 & 2709 & 2749 \\
\hline \multicolumn{7}{|c|}{ Attaining Some College } \\
\hline & $-0.083^{* * *}$ & $-0.143^{* * *}$ & $-0.045^{* *}$ & $-0.046^{* *}$ & $-0.135^{* * *}$ & -0.001 \\
\hline & $(0.024)$ & $(0.048)$ & $(0.022)$ & $(0.019)$ & $(0.027)$ & $(0.004)$ \\
\hline $\mathrm{N}$ & 1653 & 1541 & 1427 & 3011 & 2709 & 2749 \\
\hline \multicolumn{7}{|c|}{ College Completion } \\
\hline & $\begin{array}{l}-0.138^{* * *} \\
(0.032)\end{array}$ & $\begin{array}{l}-0.322 * * * \\
(0.068)\end{array}$ & $\begin{array}{l}-0.099^{* * *} \\
(0.027)\end{array}$ & $\begin{array}{l}-0.127^{* * *} \\
(0.025)\end{array}$ & $\begin{array}{l}-0.216^{* * *} \\
(0.037)\end{array}$ & $\begin{array}{l}-0.001 \\
(0.005)\end{array}$ \\
\hline $\mathrm{N}$ & 1202 & 1072 & 1109 & 2212 & 1943 & 2129 \\
\hline
\end{tabular}

$* \mathrm{p}<0.10,{ }^{* *} \mathrm{p}<0.05,{ }^{* * *} \mathrm{p}<0.01$. Bankruptcy is available for the entire sample (but not the 19995 survey), and was estimated using OLS. 